\title{
"Don't Ask, Don't Tell" and the National Guard: Federal Policies on Homosexuality in the Military vs. the Militia Clauses of the Constitution
}

\author{
Sam Ruby†
}

The Militia Clauses of the Constitution specifically reserve to the states the power to appoint officers in the militia, while granting other powers over the militia to the federal government. In this century, the militia has been transformed into the National Guard and now leads a dual existence as both 50 traditional state military entities and as a federal reserve force. Inherent in both the original (Constitutional) and present (statutory) schemes lies the familiar tension of federalism. The federal government has long been hostile to the service of homosexuals in the military. Its present policy, known popularly as "Don't Ask, Don't Tell," purportedly introduces tolerance of homosexual orientation ("Don't Ask") but effectively requires the discharge of any member who admits to being gay, lesbian, or bisexual ("Don't Tell"). A particular state, on the other hand, might conclude that homosexuals are as fit as anyone else to perform traditional militia functions-disaster relief and emergency law enforcement-and might wish to employ such individuals. Indeed, some states may positively be prohibited from discriminating against homosexuals as a matter of state law. What happens, then, when a state wishes, or is compelled, to retain a homosexual Guardsman, but the federal government says no? The author argues that mere federalization of the militia by statute cannot revoke states' rights as guaranteed by the federal Constitution. The author concludes that the applicability of "Don't Ask, Don't Tell" to the militia must ultimately turn on a balancing of Congress' power to "discipline," and thus implicitly to discharge military officers, against the states' power to "appoint," and thus implicitly to retain them.

Copyright $\odot$ I997 California Law Review, Inc.

$\dagger \quad$ A.B., University of California at Berkeley, 1994; J.D., University of California at Berkeley (Boalt HalI), 1997. Thanks to editors Tom Kennedy and Matt Falley, and to Keith Fong for putting me onto this interesting issue and case. 


\section{INTRODUCTION}

For well over a decade, the issue of "gays in the military" has been litigated in federal courts across America. However, with the inauguration of President Clinton-who as a candidate had promised to end the military's anti-homosexual posture-the debate assumed a new national prominence, in both the media and government.' In the wake of that debate, Congress adopted, and President Clinton approved, a new policy governing the service of homosexuals in the armed forces. ${ }^{2}$ That policy is perhaps best known by its popular moniker, "Don't Ask, Don't Tell." 3

On its face, "Don't Ask, Don't Tell" repudiated long-standing military policy by declaring that homosexual orientation is not a bar to military service. At the same time, however, the policy reaffirmed that "homosexual conduct" is. ${ }^{4}$ The confusing, if not unconvincing, line that the policy draws between "orientation" and "conduct" has led some commentators to ask whether "Don't Ask, Don't Tell" is a genuine departure from the policy that preceded it.

The policy has also been challenged in the courts. In one recent case, Holmes v. California Army National Guard, ${ }^{5}$ a former officer in the California Army National Guard brought suit against various federal and state defendants after being discharged under the policy. At the center of Lieutenant Holmes' many challenges to his discharge were alleged violations of his equal protection and free speech rights under the U.S. Constitution. ${ }^{6}$ These are the usual claims brought by discharged homosexual servicemembers against the federal military. ${ }^{7}$ Lieutenant Holmes also contended, however, that his discharge violated his rights under the California Constitution. ${ }^{8}$ Those rights were implicated because Lieutenant Holmes belonged not to the regular army but to the National Guard, which is in part a state entity. ${ }^{9}$

The California defendants-the governor and the adjutant general (the state's chief military officer)—moved to dismiss all claims against

1. See infra notes 151-54 and accompanying text.

2. See infra notes 154-54 and accompanying text.

3. Strictly speaking, there is no single "Don't Ask, Don't Tell" policy. There is a congressional policy that has been codified as a statute; there are Department of Defense Directives that refine it; and each branch of the armed forces has its own specific regulations that implement it. Nonetheless, in keeping with the convention that has arisen in the commentary and case law, I shall refer to all of these provisions collectively as "Don't Ask, Don't Tell," or more simply, "the policy."

4. See infra notes 156-64 and accompanying text.

5. Holmes v. California Army Nat'l Guard, 920 F. Supp. 1510 (N.D. Cal. 1996).

6. See id. at 1518.

7. See, e.g., Meinhold v. Dep't. of Defense, 34 F.3d 1469 (9th Cir. 1994); Pruitt v. Cheney, 963 F.2d 1160 (9th Cir. 1991).

8. See Holmes, $920 \mathrm{~F}$. Supp. at 1517.

9. The dual nature of the National Guard is discussed infra, Part I. 
them. ${ }^{10}$ They argued primarily that they could not be held liable for any possible unconstitutional action because their role in Lieutenant Holmes' discharge was entirely controlled by federal law. ${ }^{11}$ In other words, they had no authority to resist the application of "Don't Ask, Don't Tell." The district court rejected this contention and ruled that, under the Militia Clauses of the Constitution, ${ }^{12}$ state adherence to the policy is a matter of choice, not compulsion. Nevertheless, for other reasons, the court did not reach Lieutenant Holmes' state law claims. ${ }^{13}$

This Comment will review the Holmes case and some of its unanswered questions. My focus will be limited to the unique aspects of the Holmes case. The wisdom and constitutionality of "Don't Ask, Don't Tell" have been addressed elsewhere. This Comment examines the more novel question raised by Holmes of whether an openly homosexual person may serve as an officer in a state's National Guard despite his ineligibility under federal policies.

This issue may be of considerable practical concern to state military officers and homosexual Guardsmen. If state military officials act as state agents when they discharge National Guard officers, their actions are subject to scrutiny under state law as well as federal law. This fact is significant because "Don't Ask, Don't Tell" may violate state law even if it passes federal constitutional muster. Consequently, National Guard officers, unlike their counterparts in the regular armed forces, may have available to them an alternative forum in which to seek relief: state court.

The issue addressed in this Comment is also significant from a more academic standpoint. The Holmes case asks us to consider whether the states' constitutional right to appoint National Guard officers is offended by federal control over the discharge of those officers. It also asks us to interpret the scope of Congress' power to "discipline" the National Guard. In both respects, Holmes deals with a familiar problem: how to construe the proper balance of power between the states and the federal government in accord with the Constitution.

In Part I of this Comment, I aim to provide the necessary background to these issues. I begin with a review of the history of the National Guard, starting with its roots in the "militia" system of Europe and the American colonies. I also examine the evolving concept of a "militia" and mention some of the American militia's exploits. My primary focus, however, will be on the legislative movements that have shaped the modern National Guard. In Part II, I discuss the military's

10. See Holmes, 920 F. Supp. at 1518.

11. See id. at 1522 .

12. See id. at 1523; see also infra notes 37-44 and accompanying text.

13. See Holmes, 920 F. Supp. at 1519-21. 
policy concerning homosexuality and the debate surrounding it. I conclude Part II with a more detailed introduction to the Holmes case.

In Parts III and IV, I analyze the federal issues that Holmes raises. Generally, I examine the extent of Congress' power to exclude homosexuals from the National Guard. In Part III, I argue that the present system of "federal recognition" of National Guard officers, the operation of which most proximately caused Lieutenant Holmes' discharge, cannot be directly imposed upon the states. Rather, adherence to the federal recognition system is merely a condition attached to federal spending on the National Guard, a program which the states are constitutionally (if not financially) free to ignore. In Part IV, I argue that while Congress' power to "discipline" the National Guard is perhaps greater than some courts have assumed, that power is not absolute and must be balanced against state interests as protected by the Constitution. Accordingly, I conclude that the states are free to reject "Don't Ask, Don't Tell" so long as they are willing to risk a loss of federal funds.

I conclude with some comments on the state law issues raised by Lieutenant Holmes that the district court did not reach. Because these issues could easily command several comments of their own, I do not attempt to review them completely. Some mention of the state law aspect is necessary, however, to appreciate fully what is at stake. I shall suggest that in California, and perhaps other states, the state constitution's relatively greater protections of individual liberties raise the possibility that "Don't Ask, Don't Tell" would not survive a state law challenge. Thus, it may be that state governments are not merely permitted under the federal Constitution to dispense with "Don't Ask, Don't Tell," they may positively be required to do so by their own constitutions.

\section{The National Guard}

The National Guard is in many respects an entity that the framers would have referred to as the "militia." In this Part, I discuss the evolution of the militia in America, from its roots in Europe and the colonies, to its current existence as a joint state-federal entity. I focus on the legislative movements that have most significantly shaped the modern militia rather than its military exploits. Those movements culminated, respectively, in the Militia Clauses of the Constitution and the Second Amendment, the Dick Act of 1903 (amended in 1908), and the National Defense Act of 1916 (amended in 1920 and again in 1933). I conclude with some general comments on the structure and activities of today's National Guard. ${ }^{14}$

14. I admit that my rendition of the history of the National Guard is probably more detailed than is strictly necessary to approach the narrow legal questions raised in this Comment. However, my 


\section{A. Origins of the Militia System}

Scholars have traced the fundamental principle underlying the Anglo-American military tradition back to medieval Germany. ${ }^{15}$ John $K$. Mahon, a widely-recognized National Guard historian, identifies that principle as the "obligation of every able-bodied man to defend his society."16 In its most general form, the historical militia consisted of every single "able-bodied" adult male who, in the event of an invasion, would be called upon to take up arms and fight off the invaders. ${ }^{17}$ In England, the tradition of a select militia also developed. ${ }^{18}$ Whereas members of the general militia would, except in times of actual crisis, lead entirely civilian lives, members of the select militia would periodically train together to acquire some proficiency in the art of warfare. ${ }^{19}$

The militia system in England was an alternative to the maintenance of "standing armies"-full-time, professional military forces that began to take form in Europe in the middle of the sixteenth century. ${ }^{20}$ Some monarchs relied upon the militia because they simply could not afford standing armies. ${ }^{21}$ Rulers who could afford them were increasingly opposed by more democratic elements, particularly the rising English Parliament, many of wlose members viewed standing armies as a menace, the instrument of royal oppression. ${ }^{22}$ The Englisl found the militia to be a viable alternative because they held "a belief in the invincibility of citizen soldiers when fighting for home and family."23

\section{B. The Militia in Colonial America}

In the American colonies, the often imminent threat of hostilities (usually with Native Americans and occasionally with other colonial powers) and the paucity of professional soldiers made the militia system a necessity.$^{24}$ Implicitly, and sometimes explicitly, the charters granted to the American colonies authorized the colonial governments to establish

experience indicates that most people are unfamiliar with both the National Guard and the concept of a "militia." Furthermore, current events have led to some misconceptions as to what a "militia" is. I would like to dispel such misconceptions.

15. See, e.g., John K. Mahon, History of the Militia and the National GuaRd 6 (1983) (discussing early European militia traditions and their contributions to English history).

I6. Id.

17. See id.

18. See id.

19. See id. at 6-13.

20. See id. at 8-9.

2I. See id. at $8,10$.

22. See id. at 12-13.

23. Id. at $\mathrm{IO}$.

24. See William H. Riker, Soldiers of the States 11 (1957). 
militias and compel all eligible settlers to serve in defense of the colony. ${ }^{25}$ By 1671 , all the existing colonies had exercised this authority ${ }^{26}$

The colonial militias differed in organization and discipline. ${ }^{27}$ The militias generally provided an adequate defense against Indian attacks, but when the British Empire employed militiamen in the French and Indian War (1754-1763), their record was spotty. ${ }^{28}$ Nonetheless, despite continuing breakdowns in discipline and a lack of training, the militias served an indispensable role in the army that fought the American Revolution. ${ }^{29}$ As a result, many militia units and officers established for themselves a firm place in American history ${ }^{30}$

After the war, nearly all federal troops were disbanded." Thus, "the military affairs of the nation were for all practical purposes placed entirely in the hands of state governments." ${ }^{.32}$ Unfortunately, the Articles of Confederation, ratified in 1781, provided little assurance that the states would live up to this arrangement by maintaining the disciplined and well-regulated militias that the Articles required. ${ }^{33}$

In 1786, Shay's Rebellion made plain the resulting "absence of a unified defense for the new country." ${ }^{34}$ In that debacle, the Commonwealth of Massachusetts "resisted attempts by the confederated government to send armed forces to suppress the rebels."35 Eventually, wealthy interests in the eastern part of the state were able to raise a sufficient force to break the rebellion. ${ }^{36}$

The use of citizen soldiers to suppress rioters became the pattern for dealing with insurrections in the last decade of the eighteenth century. The difficulty in suppressing Shays' Rebellion was only one episode that convinced former leaders of the Revolution that the Articles of Confederation were too weak.... Pressure from these men led to the calling of the Constitutional Convention which assembled in May 1787 in Philadelphia. ${ }^{37}$

25. See MAHON, supra note 15 , at 14.

26. See RiKer, supra note 24, at 11.

27. See MAHON, supra note 15 , at 31.

28. See id. at 28-30 (recounting the successes and failures of the American militiamen during the French and Indian War); id. at 32-33 (evaluating the overall strengths and weaknesses of the militia system prior to the American Revolution).

29. See RiKer, supra note 24, at 11.

30. See MaHON, supra note 15 , at 35-45 (discussing the militia's involvement in the Revolutionary War).

31. See Riker, supra note 24 , at 11.

32. Id.

33. See MAHON, supra note 15 , at 46 .

34. advisory Commission on Intergovernmental Relations, The National Guard: Defending the Nation and the States 7 (1993) [hereinafter Advisory Commission].

35. Id.

36. See MAHON, supra note 15 , at 47.

37. Id. 
The need to maintain civil order, brought to light by this episode, became another factor that influenced the American militia tradition.

\section{The Militia and the Constitution}

Few of the participants in the Philadelphia Convention of 1787 doubted the need for a strong militia. ${ }^{38}$ Opinions differed, however, as to who should control it. Although the framers were mostly moderates amiable to compromise, extremists on both sides provoked a lively debate. Alexander Hamilton favored complete federal control over the militia. ${ }^{39}$ Elbridge Gerry vociferously resisted the transfer of any control from the states to the federal government. ${ }^{40}$ As with most issues tackled during the Convention, the moderates eventually carried the day, and a compromise was reached.

The provisions ultimately adopted by the Convention appear in Article I, Section 8. The fifteenth clause of Section 8 establishes the purposes towards which the federal government can employ the militia. It grants Congress the power " $[t] \circ$ provide for calling forth the [m]ilitia to execute the [1]aws of the Union, suppress [i]nsurrections and repel [i]nvasions." ${ }^{21}$ This provision struck a compromise by making the militia available to the federal government, but only for limited purposes. Once called out by Congress, the militia is under the control of the President in his capacity as commander-in-chief. ${ }^{42}$

The sixteenth clause of Section 8 divides control over the militia between the states and Congress. The clause grants Congress the power "[t]o provide for organizing, arming, and disciplining, the [m]ilitia, and for goveruing such [p]art of them as may be employed in the [s]ervice of the United States...."43 The clause reserves to the states "the [a]ppointment of the [o]fficers, and the [a]uthority of training the [m]ilitia" although such training must be conducted "according to the discipline prescribed by Congress." 44 Together, these two clauses are commonly referred to as the Militia Clauses of the Constitution. ${ }^{45}$

38. See Alan Hirsch, The Militia Clauses of the Constitution and the National Guard, $56 \mathrm{U}$. CiN. L. REv. 919, 924 (1988). Given the Colonies' vulnerability under the Articles of Confederation to foreign invasion and civil disorder, the military capability of the nation had to be increased. At the same time, the idea of a large standing army remained extremely unpopular. See id. Thus, most considered a strong militia desirable.

39. See 1 Records of the Federal Convention of 1787, at 293 (Max Farrand ed., 1911) [hereinafter FARRAND].

40. See RiKER, supra note 24 , at 15 .

41. U.S. CoNsT. art. I, \& 8, cl. 15.

42. See id. art. 1I, § 2, cl. 1. Over time, Congress delegated more and more of its Article I authority to call out the militia to the President.

43. Id. art. I, § 8, cl. 16.

44. Id.

45. See, e.g., Perpich v. Dep't. of Defense, 496 U.S. 334, 337 n.3 (1990); Patrick Todd Mullins, Note, The Militia Clauses, the National Guard, and Federalism: A Constitutional Tug of War, 57 Geo. 
The Militia Clauses proved to be an explosive issue during the ratification debates that followed the Convention. Anti-federalists seized upon the considerable grant of authority over the militia to the federal government, attacking it as an example of the means the new government would have in subjugating the states. ${ }^{46}$ Patrick Henry, for example, decried the lack of an explicit statement that the states retained concurrent authority to organize, arm, and discipline the militia. ${ }^{47}$

Anti-federalist arguments made an impression upon many moderates who began to feel that the Militia Clauses did not adequately safeguard the integrity of the state militias and, thereby, the sovereignty of the states. Eventually, avowed Federalists realized as a practical matter that perceived weaknesses in the Militia Clauses threatened to derail ratification. ${ }^{48}$ The result was a proliferation of proposed amendments to strengthen the position of the states with respect to the militia. ${ }^{49}$

The first Congress responded to these concerns by adopting, with little debate, what became the Second Amendment. ${ }^{50}$ That amendment provides that "[a] well regulated [m]ilitia, being necessary to the security of a free [s]tate, the right of the people to keep and bear [a]rms, shall not be infringed." 51 The Second Amendment ensured that the federal government could not destroy the state militias by disarming them. ${ }^{52}$ On the other hand, it did not completely allay the fears that Henry had aroused, because it did not specifically state that the authority to organize, arm, and discipline the militia was concurrent in both the states and the federal government. ${ }^{53}$

Commentators suggest that, on the subject of the militia, the Framers were more articulate of their vision of federalism and the separation of powers than in any other area of the Constitution. William Riker notes that "the [Militia Clauses] and the Second Amendment together are one of the most definite and precise statements to be found in the whole Constitution of the federal guarantee of the continued existence and integrity of constituent governments." ${ }^{4}$ Likewise, John Mahon posits that "as in the entire Constitution, the object was to

WASH. L. REv, 328, 330 (1988). In earlier jurisprudence and commentary, the provisions were referred to as a single "Militia Clause." See, e.g., Selective Draft Law Cases, 245 U.S. 366, 372 (1918); Frederick Bernays Wiener, The Militia Clause of the Constitution, 54 Harv. L. Rev. 181 (1940).

46. See RIKER, supra note 24, at 16-17. A leading proponent of this theory was Luther Martin, in Maryland. See id. at 16.

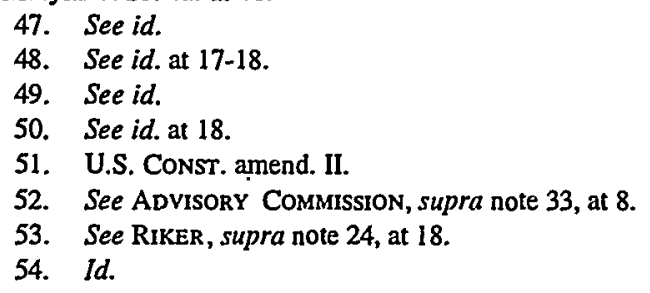


prevent the accumulation of overwhelming power in any person or agency" by "split[ting] power into fragments." ${ }^{\text {" }} \mathrm{He}$ concludes that "in no part of the document was this done in more detail than in the

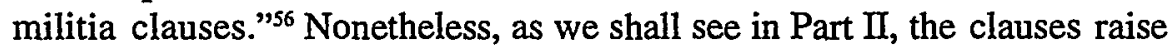
difficult questions about their meaning, despite their specificity.

After adopting the Second Amendment, Congress passed the Militia Act of 1792, exercising for the first time its powers under the Militia Clauses. The exercise was minimal. The Act did little more than recommend to the states that they get their militias in order and keep Congress informed of their progress. ${ }^{57}$ Freedom from federal interference, which had eluded states' rights advocates during the drafting and ratification of the Constitution, was thus largely achieved by statute. ${ }^{58}$ This state of affairs would remain basically unchanged for 111 years, until the aftermath of the War with Spain. ${ }^{59}$

\section{Birth of the National Guards}

The Act of 1792 envisioned a general militia. It required all males of a certain age to enroll in the militia of their state and to supply themselves with arms and equipment. ${ }^{61}$ The "enrolled" militia, however, was ignored by the federal government and often neglected by the states, resulting in its steady decline. ${ }^{61}$

While the enrolled militia was "dying a slow death in most areas of the country," ${ }^{62}$ a new kind of militia organization (contemplated but not emphasized by the Militia Act of 1792) began to appear. Men interested in military drill and camaraderie were drawing together in volunteer militia companies. ${ }^{63}$ Often ethnic groups, particularly recent immigrants, formed these volunteer militia units. ${ }^{64}$ The volunteer units also appealed to the middle and upper classes, for whom state military commissions provided distinction and status. ${ }^{65}$ These volunteer units were the

55. MAHON, supra note 15 , at 49.

56. Id.

57. See RIKER, supra note 24 , at 19-20 (discussing the debate over, and ultimate provisions of, the Militia Act of 1792).

58. See id. at 20; MAHON, supra note 15, at 56 (concluding that the act "amounted to virtual abdication by the federal government of all authority over the state militias").

59. See RiKer, supra note 24 , at 18 ; see generally id. at 21.60 (discussing national militia policy during the nineteenth century).

60. See Wiener, supra note 45 , at 187.

61. See RiKer, supra note 24, at 21-40 (discussing the "Degeneration of the Militia, 17921860"); MAHON, supra note 14, at 78-96 (discussing the "Decline of the Militia").

62. See Advisory Commission, supra note 34, at 9 (quoting Robert K. Wright, JR. \& Renee Hylton-Greene, a Brief History of the Militia and the National Guard 14 (1986)).

63. See id.

64. See id.

65. See MAHON, supra note 15 , at 83. 
forerunners of the modern state militaries, the National Guards. Increasingly, states relied on the volunteer militia rather than the enrolled (and usually unorganized) militia. As Mahon explains,

the volunteer militia were useful to state and local officials in maintaining law and order. They guarded prisoners to prevent lynchings and prisons where unpopular executions were being carried out. They enforced quarantines. Riot duty was an integral part of their service, for riots were endemic to the cities. ${ }^{66}$

Both the enrolled and volunteer militias virtually disappeared in the course of the Civil War. ${ }^{67}$ The enrolled militia never recovered. ${ }^{68}$ Volunteer militias, however, experienced a revival in the 1870s. Following New York's lead, ${ }^{69}$ states reconstituted these organizations under the name of "National Guards." Increasing labor strife stimulated interest in and support for the National Guards, ${ }^{71}$ and post-war nostalgia for the ideal of military service helped fuel the revival. ${ }^{72}$ The "social club features" of Guard membership, ${ }^{73}$ rifle training, marksmanship competitions, ${ }^{74}$ and the opportunity to wear fancy (even gaudy) uniforms and march in parades also attracted volunteers. ${ }^{75}$

The National Guard Association, a lobbying organization comprised of officers of the state Guards, became adept at winning appropriations from both the states and the federal government. ${ }^{76}$ To do so at the national level, however, it had to overcome the Guard's image as a strike-breaking police force or social extravagance by emphasizing its potential as a genuine component of national defense. ${ }^{77}$ The rise of the Guards in the final quarter of the nineteenth century, along with the National Guard Association's efforts to seek a recognized place for the Guard in the national military structure, partially led to the overhaul of the national militia system in 1903.

The Spanish-American War (1898-1899) was also instrumental in bringing about reform. The participation of National Guardsmen in the

66. Id. at 85 .

67. See id. at 108; see RIKER, supra note 24, at $44-46$ (discussing the state of the militia in the immediate post-war period).

68. See Wiener, supra note 45 , at 191.

69. See ADVISORY COMmission, supra note 34 , at 9.

70. "By 1896 , only three states were not using [the name] for their organized militia." MAHON, supra note 14 , at 110 .

71. See RiKer, supra note 24, at 47-55.

72. See Martha Derthick, The National Guard in Politics 17-18 (1965).

73. RIKER, supra note 24 , at 57 .

74. See id. at 57-58.

75. See id. at 58-59; Wiener, supra note 45 , at 191.

76. See DERTHICK, supra note 72 , at $20-22$ (discussing the Association's improvement in lobbying); RIKER, supra note 23, at 59-60 (same).

77. See RIKER, supra note 24 , at 61 . 
war was considerable. ${ }^{78}$ However, Guard units could not simply volunteer as a unit due to the legal strictures on induction into the army. Rather, they had to volunteer as individuals and hope that, once inducted, they would be able to draw together. ${ }^{79}$ At least one premiere unit, the Seventh New York Infantry, chose not to disband as a militia regiment and regroup in the volunteer army for fear of losing its identity. ${ }^{80}$ The system also disadvantaged high-ranking officers, who might not be accepted; "many militia generals did not obtain United States commissions." The war thus strengthened the National Guard Association's resolve to accomplish serious militia reform.

Eventually, the national government also began to express a serious interest in militia reform. The war revealed the obsolescence and inefficiency of the national military structure and the pathetic state of readiness and competency within the services. ${ }^{82}$ But, "[i]f the nation was shocked by the state of the army at the beginning of the Spanish war, the army was even more shocked by the state of the militia." 83 President Roosevelt and his Secretary of War, Elihu Root, were determined to repeal the Militia Act of 1792 and replace it with legislation that would improve both the quality of the Guards and the procedures for bringing them into active military service. ${ }^{84}$ For the first time in American history, the pieces were in place for the formulation of a strong national militia policy.

\section{E. The Dick Act of 1903}

After putting the army's house in order, ${ }^{85}$ Root, with the active help of the National Guard Association, ${ }^{86}$ secured passage of the Militia Act of 1903, more commonly referred to as the Dick Act. ${ }^{87}$ Most significantly for the National Guards, the act provided that the militia would be the first source of reserves (rather than volunteers) in the case

78. See MAHON, supra note 15, at 125-37 (discussing the Spanish-American War and the National Guard's involvement in it).

79. See id. at 136.

80. See id. at 126.

81. RIKER, supra note 24 , at 69 .

82. See id. at 69; Wiener, supra note 45, at 192.

83. RiKER, supra note 24 , at 69.

84. See RIKER, supra note 24 , at 69 ; Wiener, supra note 45 , at 194-95.

85. Root succeeded in reorganizing the structure of the Army and creating a General Staff, bringing the United States Army into the modern age. See Wiener, supra note 45, at 193.

86. See DERTHICK, supra note 72, at 23.

87. See, e.g., Advisory Commission, supra note 34, at 10. General Charles F. Dick was the chairman of the Militia Committee in the House of Representatives; he was also the commanding general of the Ohio National Guard and the president of the National Guard Association. Although the militia reform bill bore his name, Dick's precise role in the movement is unclear. Derthick suggests that Root was the real force at work. See DERTHICK, supra note 72, at 26-27. 
of domestic emergencies. ${ }^{88}$ When called, the militia could be used for up to nine months. ${ }^{89}$ Partial federal funding of the state Guards would be continued through an increased grant-in-aid. ${ }^{90}$

Those funds, however, now came with strings attached. The federal government, particularly the army, had to get something out of the deal. What it received was an increased role in the operation of the Guards, a degree of control perhaps contemplated by the Constitution but never before asserted. In return for federal assistance, the states were required, within a period of years, to organize their Guards in conformity with the regular army's tables of organization. ${ }^{91}$ The Guards were required to conduct a minimum of twenty-four drills a year, plus a five-day summer camp. ${ }^{92}$ Regular army officers would inspect units and, with some limitations, participate in their training. ${ }^{93}$

Although these "requirements" were attached to the grant-in-aid, the Dick Act did not contain any actual mechanism for cutting off a state's funds if it failed to comply with the Act's provisions. ${ }^{94}$ Nonetheless, in the context of the history of the American militia, the amount of control placed in the hands of the national government and military was staggering. According to Riker, "[a]stonishingly enough, the militant advocates of states' rights did not object to the control. Indeed, they did not even seem to notice it."

The debate over the Militia Clauses had been vigorous. ${ }^{96}$ How was it that the Dick Act passed with hardly a whimper from the many steadfast defenders of states' rights within and outside the Guards? Historians suggest that the Guards were too happy with the funds and recognition they had received to worry about the downside of the bargain. ${ }^{97}$ Moreover, the Guards were too busy fighting off what they conceived to be a greater threat: the establishment of an entirely federal reserve army with no connection to the states. ${ }^{98}$ The Guards viewed such an organization, long urged by military planners dissatisfied with the militia system, as a rival. It could take the Guards' place in the national defense structure and, soon thereafter, the Guards' funds. During the passage of the Dick Act, the Guards focused their opposition on a provision that would have

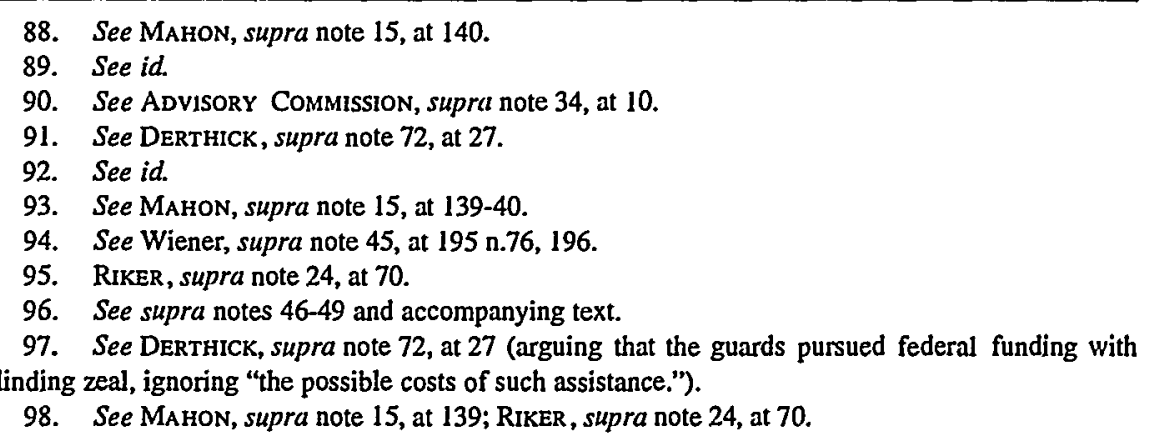


established a volunteer federal reserve. ${ }^{99}$ Although they were successful, Riker concludes that by tolerating increased federal control in order to avoid competition with a federal reserve, the states' rights advocates "fought an imaginary threat to state control and allowed a very real threat to pass unchallenged." 100

Congress amended the Dick Act in 1908 in a fashion generally favorable to the Guards. ${ }^{101}$ Congress increased the annual appropriation. ${ }^{102}$ The militia would be preferred over volunteers to support the army not only in domestic emergencies, but in all military operations inside and outside the country.$^{103}$ Restrictions on the length of service-nine months under the original Act-were lifted as well. ${ }^{104}$ The result, firm recognition of the militia's high place in national military affairs, was "absolute assurance of a place at the front, right behind the Army."

\section{F. The National Defense Act of 1916}

As military planners continued to evaluate the country's national security needs and war in Europe approached, national militia policy continued to develop. Advocates repeatedly pressed the issue of a federal reserve force. ${ }^{106}$ Meanwhile, the Guards conducted a major campaign to win "drill pay," that is, federal funding for the drills the Guards were required to conduct under the Dick Act. ${ }^{107}$ Thus, militia policy was very much a live topic in the years following the Dick Act amendments, although little would be resolved until 1916.

Other factors brought the growing agitation for further militia legislation to a head. The 1908 amendment authorizing the use of Guardsmen outside the territory of the United States was effectively nullified by an opinion issued by the Attorney General in 1912. The Attorney General, with the concurrence of the Judge Advocate General of the Army, held that the first Militia Clause limited use of the militia to defensive purposes only. ${ }^{108}$ The opinion strengthened the position of those who argued that the Guards simply could not serve the national security needs of a modern world power. Foreign affairs pushed matters along as well. Upheaval in Mexico led to increasing concern about the

\footnotetext{
99. See MaHon, supra note 15 , at 139.

100. RIKER, supra note 24 , at 70.

101. See id. at 71.

102. See id.

103. See DERTHICK, supra note 72 , at 28 .

104. See id.

105. Id.

106. The Army War College, the General Staff, and the War Department all advanced various plans during this period. For a description, see RiKER, supra note 24 , at 72-77.

107. See DerThICK, supra note 72, at 29-32 (discussing the National Guard Association's campaign for drill pay).

108. See 29 Op. Att'y Gen. 322 (1912).
} 
security of the border. ${ }^{109}$ War in Europe stirred concern about American military preparedness. The hypothetical need for a reserve force that could support the army in operations outside of the country was looking less and less hypothetical. ${ }^{110}$

All of these developments resulted in the National Defense Act of 1916. All interested parties essentially got what they wanted (and consequently, what they did not want as well). The army won its reserve force-two, in fact: the Officer's Reserve Corps and the Enlisted Reserve Corps. ${ }^{11}$ The Guards won federal funding for drills, summer camps, and administrative work. ${ }^{112}$

Federal control over the Guards increased under the 1916 Act. The National Defense Act compelled the Guards to conduct more drills and a longer summer camp. ${ }^{133}$ It provided for even more federal control over organization, training, and discipline. ${ }^{114}$ Unlike the Dick Act, the National Defense Act provided that states would lose their National Guard appropriation if they did not submit to federal authority. ${ }^{115}$ Most significantly, the Act introduced "federal recognition" of National Guard officers. Under this system, the army, not the states, would determine the minimum qualifications for National Guard officers. A stateappointed officer who met the qualifications would receive a grant of "federal recognition" and would thereby be eligible for federal pay. ${ }^{116}$

Furthermore, the National Defense Act resolved the problem, at least for a while, of using the National Guard for purposes other than those contemplated by the First Militia Clause. ${ }^{117}$ All Guardsmen were required to take a dual oath, one to their respective states as usual, and now, one to the nation as well. ${ }^{118}$ Having done so, they could be drafted into federal service by the President. ${ }^{119}$ Once drafted, a Guardsman was no longer a militiaman, but a solider like any other. As such, his use was not limited by the First Militia Clause. Rather, he was at the complete disposal of the federal government exercising its unlimited authority under the Army Clause and other war powers provisions in the

109. See Wiener, supra note 45 , at 198.

110. Indeed, the Attorney General's 1912 opinion had addressed the question of "whether the National Guard could be used as an Army of Occupation in Mexico." Id.

111. See MAHON, supra note 15, at 148.

112. See Wiener, supra note 45 , at 200.

113. See RiKER, supra note 24, at 81-82.

114. See id.

115. See Wiener, supra note 45 , at 200.

116. See id. at 201.

117. For example, "other purposes" include offensive, extraterritorial operations. Recall that the First Militia Clause restricts federal use of the militia to law enforcement, suppression of rebellion, and thwarting invasions. See U.S. CoNST. art. 1, § 8, cl. 15.

118. See Wiener, supra note 45 , at 201.

119. See id. 
Constitution. ${ }^{120}$ The United States soon resorted to the draft provisions of the National Defense Act as the country mobilized to enter World War I. ${ }^{121}$

In the aftermath of the war, Congress amended the National Defense Act. The 1920 amendments affected the National Guards in several respects, three of which are relevant to this discussion. During the war, so many Guardsmen had been drafted, and at that point-under the terms of the Act as it then existed - discharged from the militia, that the National Guards barely existed when the war was over. ${ }^{122}$ Therefore, Congress amended the draft provisions of the Act to make it clear that the states "were free to provide that a Guardsman should not be dis- charged from the militia after a draft into federal service." ${ }^{123}$ Second, the amendments made National Guard officers eligible to receive federal commissions in the Officers' Reserve Corps. ${ }^{124}$ Third, the amendments included a "simple statement that the Guard, when in federal service, was a component of the Army of the United States."125

Dissatisfaction with at least two of these amendments ultimately led to a further round of revisions in 1933. Although the granting of Reserve commissions would facilitate the entry of National Guard officers into federal service, the officers' status as Reservists meant that they could be assigned to any unit in the army. They might be separated from the men they commanded in peacetime. ${ }^{126}$ Enlisted men, of course, had no guarantee either that they would remain with their comrades once drafted. Thus, even after the 1920 amendments, unit integrity was no more assured than it had been under the Dick Act. Second, the new definition of the army of the United States, which included the Guards when in federal service, consequently excluded the Guards when in state service. ${ }^{127}$ Unlike the federal Reserves, the Guards were not "really" a part of the national armed forces until called up or drafted. Full recognition of their importance had thus not been achieved.

Legislation in 1933 addressed both of these concerns and established the modern structure of the National Guard, which persists largely unchanged. The state Guards would continue to exist as the incarnation of the American militia; they would be "organized and administered under the [M]ilitia [C]lause of the Constitution, and available only for

120. See Selective Draft Law Cases, 245 U.S. 366 (1918) (upholding the constitutionality of the National Defense Act's draft provisions).

121. See Wiener, supra note 45 , at 203-04.

122. See id. at 205.

123. Id. at 206.

124. See id. Most National Guard officers did acquire Reserve commissions. See id. at 206 n.144.

125. MAHON, supra note 15 , at 171.

126. See RikeR, supra note 24 , at 86 .

127. See Wiener, supra note 45 , at 207. 
limited duties."128 However, there would now exist a "National Guard of the United States," a wholly federal reserve force, organized and administered under the Army Clause. ${ }^{129}$ Unlike the state Guards, the National Guard of the United States would at all times be a component of the United States Army. ${ }^{130}$ The National Guard of the United States was to consist of "federally recognized [state] National Guard units which had been specifically admitted into it."131 Thus, the federal recognition system, which previously applied only to officers, would now apply to entire units. Physically then, the "new" federal Guard would be coextensive with the sum of the federally-recognized state Guard units, though legally it would exist as a separate entity.

The new system served several of the goals that the state Guards and the national government had pursued for so long. The primary benefit from the Guards' perspective was that unit integrity would be more or less assured since entire units would receive federal recognition. ${ }^{132}$ The federal government, meanwhile, no longer had to go through the trouble of "calling forth" the Guards under the First Militia Clause or drafting them into the army, as it did under the 1916 provisions. Guardsmen would already be in a component of the army and could simply be ordered to report for active duty. ${ }^{133}$

\section{G. The National Guard Today}

The "dual enlistment" system established by the 1933 amendments remains in effect today. Every person who enlists in a state Guard simultaneously enlists in the National Guard of the United States. ${ }^{134}$ As the Supreme Court has explained, National Guardsmen "now must keep three hats in their closets-a civilian hat, a state militia hat, and an army hat." $" 135$

In keeping with the provision of the Second Militia Clause that reserves to the states the power to appoint militia officers (henceforth, the "officering power"), officers are first commissioned in a state National Guard. ${ }^{136}$ Assuming they meet federal standards, they are granted "federal recognition," which means they are qualified to command units in the National Guard of the United States. An officer's "capacity

128. Id. at 208.

129. See id.

130. See id.

131. MAHON, supra note 15 , at 174.

132. See RIKER, supra note 24 , at 85 .

133. See id. Of course, there is nothing to stop the federal government from taking control of and employing the National Guards under the First Militia Clause, since the National Guards are still the militia. However, their use is then limited to those purposes contemplated by the Constitution.

134. See Perpich v. Dep't of Defense, 496 U.S. 334, 345 (1990).

135. Id. at 348 .

136. Holmes v. California Army Nat'l Guard, 920 F. Supp. 1510, 1521 (N.D. Cal. 1996). 
and general fitness" to retain his federal recognition can be investigated at any time by an efficiency board..$^{137}$ The Chief of the National Guard Bureau then reviews the findings and recommendations of the efficiency board. ${ }^{138}$ The Burean, if it agrees with a negative report, can strip the officer of federal recognition. ${ }^{139}$ Loss of federal recognition generally results in the officer's discharge from his state National Guard. ${ }^{140}$

In many ways, the National Guard today bears little resemblance to the state militias of old. In organization, eqnipment, and training, the Guard is virtually indistinguishable from the regular armed forces. Rather than merely repelling invasions, the Guard now supports the army and the air force in offensive military operations aronnd the world. ${ }^{141}$ An entity which was traditionally used to preserve civil order now maintains units such as "Military Intelligence Battalions," which "collect and analyze tactical and strategic battle information."

Nonetheless, most of the time Guard nnits are not in active federal service and are nnder the command of state governors, and their state functions have not entirely disappeared. Typically, state law provides that the governor may employ the National Guard to protect the "security of the state and its citizens," which usually means emergency law enforcement and disaster relief. ${ }^{143}$ Many states rely heavily upon the Guard in these areas. ${ }^{144}$ Therefore, despite the increasing "federalization" of the Guard, the states still hold a significant interest in the organization, structure, training, and administration of their militias.

\section{II}

\section{HomoseXuals aNd THE Military}

In this section, I review the historical and current status of homosexuals in the military. First, I briefly discuss the military's previous stance on the issue, the challenges brought against it, and the events leading to the adoption of the current policy, "Don't Ask, Don't Tell." Second, I outline the relevant components of the new policy. Finally, I describe in greater detail the facts and outcome of Holmes $v$. California Army National Guard. ${ }^{145}$

137. 32 U.S.C. \$ 323(b) (1994); see Holmes, 920 F. Supp. at 1522.

138. See Holmes, 920 F. Supp. at 1522.

139. See id.

140. See infra Part III.

141. See Mullins, supra note 45 , at 339.

142. Id. at 344 .

143. Id. at 329 \& n.10. Other functions are not so typical. Recently, a National Guard unit used thermal-imaging technology to locate a Bengal tiger that had escaped from a circus. See National Guard Helps Capture Circus Tiger, The Fort Worth Star-Telegram, Feb. 11, 1995, at 25.

144. See Mahon, supra note 15 , at 264.

145. 920 F. Supp. 1510 (N.D. Cal. 1996). 


\section{A. History of the Policy}

During World War I and the inter-war period that followed, homosexuals were disciplined and expelled from the military through criminal proceedings. Military law proscribed sodomy, first classified as a type of assault and later as a distinct offense. ${ }^{146}$ Thus, there was not so much a "policy" as to homosexuals as such, but rather a policy prohibiting certain forms of conduct.

This state of affairs began to change with the onset of World War II. The military adopted a view of homosexuality as a mental illness, which might or might not successfully be "treated."147 "Untreatable" homosexuals could be discharged as unfit for military service, regardless of whether they had engaged in any conduct that could be punished under military law. ${ }^{148} \mathrm{McC}$ Carthyism cemented the military's shift from punishing homosexual conduct to excluding homosexuals altogether. ${ }^{149}$

In response to court challenges and inconsistent application of existing procedures, the military revised its policy in the early $1980 \mathrm{~s}^{150}$ The revised policy squarely announced that homosexuality was incompatible with military service, and it required the discharge of known homosexuals. ${ }^{151}$

The policy was challenged in a series of high-profile cases. ${ }^{152}$ Typically, the plaintiff in each of these cases was discharged after making a statement disclosing his or her sexual orientation. Some plaintiffs brought First Amendment claims, arguing that the policy burdened their free speech rights. Occasionally, the policy was challenged under the Fifth Amendment's guarantee of due process. However, the real battleground proved to be equal protection. While the free speech and due process claims generally met with failure, the equal protection claims were more successful.

Running for President in 1992, Governor Bill Clinton promised that he "would do for gays what Harry Truman did for blacks in 1948-eliminate the military's discriminatory policies by executive order ...." S53 Soon after his inauguration, President Clinton ordered the

146. See Kenneth S..McLaughlin, Jr., Note, Challenging the Constitutionality of President Clinton's Compromise: A Practical Alternative to the Military's "Don't Ask, Don't Tell" Policy, $28 \mathrm{~J}$. Marshall L. Rev. 179, 181 (1994).

147. See id. at 182.

148. See id.

149. See id. at $\mathbf{1 8 2 - 8 3}$

150. See id. at 184 .

151. See id.

152. A full discussion of these cases cannot be undertaken here. However, they have been reviewed elsewhere. See, e.g., Walter John Krygowski, Comment, Homosexuality and the Military Mission: The Failure of the "Don't Ask, Don't Tell" Policy, 20 U. DAYTon L. REv, 875, 888-907 (1995).

153. Tom Morganthau et al., Gays and the Military, NEwSWEEK, Feb. 1, 1993, at 52. 
Department of Defense to review its policy on homosexuality and draft an executive order eliminating sexual orientation discrimination. ${ }^{154}$ During the six months that followed, Congress, not to mention the military, registered considerable opposition to lifting the ban. ${ }^{155}$ On July 19 , 1993, President Clinton announced a compromise policy under which the military would stop asking recruits and members about their sexual orientation ("Don't Ask") but could still discharge those who voluntarily disclosed their homosexual orientation ("Don't Tell"). ${ }^{156}$ Congress codified the policy in October of 1993 as part of the National Defense Authorization Act For Fiscal Year 1994, ${ }^{157}$ and President Clinton signed it one month later.

\section{B. Elements of the Policy}

The statutory foundation of the "Don't Ask, Don't Tell" policy is 10 U.S.C. $\S 654$ ("Policy concerning homosexuality in the Armed Forces") (hereinafter, "the Act"). Subsection (a) contains fifteen Congressional "findings" which relate to the Act's justifications. Chief among these is a finding that "[t]he prohibition against homosexual conduct is a longstanding element of military law that continues to be necessary in the unique circumstances of military service." 158 Furthermore, Congress expresses a concern not only for those who actually have engaged in homosexual acts, but also for those who represent a risk of potential misconduct: "The presence in the armed forces of persons who demonstrate a propensity or intent to engage in homosexual acts would create an unacceptable risk to the high standards of morale, good order and discipline, and unit cohesion that are the essence of military capability."159

The actual discharge provisions of the Act are articulated in subsection (b). That subsection requires the discharge, or "separation," of a servicemember who has engaged in or attempted to engage in a "homosexual act"

154. See President's Memorandum for the Secretary of Defense on Ending Discrimination on the Basis of Sexual Orientation in the Armed Forces, 29 Weekly CoMp. Pres. Doc. 112 (Feb. 1, 1993).

155. See McLaughlin, supra note 146 , at 185-86.

156. See id. at 186.

157. See id. at 187-88.

158. 10 U.S.C. $\$ 654(a)(13)$ (1994).

159. Id. $\$ 654(a)(15)$. The Act does not define "propensity."

160. Id. $\$ 654(b)(1)$. "Homosexual acts" are defined broadly to include not only those specific acts (such as sodomy) prohibited by the Uniform Code of Military Justice, but also "any bodily contact . . . between members of the same sex for the purpose of satisfying sexual desires," and "any bodily contact which a reasonable person would understand to demonstrate a propensity or intent to engage in" such contacts. Id. § 654(f)(3). 
person known to be of the same biological sex."161 Furthermore, separation is mandatory if "the member has stated that he or she is a homosexual or bisexual, or words to that effect," 162 unless the servicemember can subsequently demonstrate that he or she is not someone who "engages in, attempts to engage in, has a propensity to engage in, or intends to engage in homosexual acts." the "sense of Congress" that, unless the Secretary of Defense were to conclude otherwise, questioning concerning homosexuality should be suspended. ${ }^{164}$

After the Act became law, the Department of Defense was required to amend several standing Directives. ${ }^{165}$ The Directives essentially mirror the provisions of the Act, with some important refinements. First, the Directives explicitly state that "sexual orientation is considered a personal and private matter" and that homosexual orientation is not a bar to military service. ${ }^{166}$ However, the Directives reaffirm that an admission of homosexual or bisexual orientation creates a rebuttable presumption that the speaker "engages in, attempts to engage in, has a propensity to engage in, or intends to engage in homosexual acts."167 Third, the Directives define the term "propensity" as meaning "more than an abstract preference or desire to engage in homosexual acts[,]" but rather, "a likelihood that a person engages in or will engage in homosexual acts." 168

Each branch of the military (i.e., the army, the air force, etc.) has its own specific Regulations which implement the Directives. Together, the Act, the Directives, and the Regulations comprise the federal government's policy on homosexuality in the armed forces. As before, I shall refer to all of these components collectively as "Don't Ask, Don't Tell" or "the policy."

\footnotetext{
161. Id. §654(b)(3).

162. Id. $\$ 654(\mathrm{~b})(2)$ (the "Don't Tell" provision).

163. Id.

164. Uniform Code of Military Justice, Pub. L. No. 103-160, §571(d) (1993) (the "Don't Ask" provision).

165. See Department of Defense Directive 1332.30 (1994) (Separation of Regular Commissioned Officers) [hereinafter "DoD Dir. 1332.30"]; Department of Defense Directive 1332.14 (1993) (Enlisted Administrative Separations) [hereinafter "DoD Dir. 1332.14"]; Department of Defense Directive 1304.26 (1994) (Qualification Standards for Enlistment, Appointment, and Induction) [hereinafter "DoD Dir. 1304.26"].

166. DoD Dir. 1332.30, supra note 163, I C, at 2-1; DoD Dir. 1304.26, supra note 165, at 1-5, 1-

167. DoD Dir. 1332.30, supra note 163, 9 C-1(b), at 2-2; DoD Dir. 1332.14, supra note 165 , 1 H$1(b)(2)$, at $1-10$.

168. DoD Dir. 1332.14, supra note 163, IJ, at 2-1; DoD Dir. 1332.30, supra note 165, I13, at 1-
} 6. 1. 


\section{Holmes v. California Army National Guard}

Andrew Holmes enrolled in the California Army National Guard ("CARNG") in 1986. ${ }^{169}$ Three years later, he was commissioned as a Second Lieutenant. At the same time, Lieutenant Holmes was granted federal recognition, thus making him an officer in the Army National Guard of the United States ("ARNGUS") as well.

Over the next four years, Lieutenant Holmes served with distinction. He was promoted to First Lieutenant and commanded a military police unit, which one performance reviewer described as "a shining example of cohesion."170 During Operation Desert Shield and Operation Desert Storm, Lieutenant Holmes was deployed to Germany, where he earned the Army Achievement Medal, the Army Reserve Components Achievement Medal, and the National Defense Ribbon.

Emboldened by Clinton's promise to lift the ban on homosexuals in the military, Lieutenant Holmes informed his commanding officer in 1993 that he was gay. His commander responded by submitting a request that Lieutenant Holmes' federal recognition be withdrawn. Discharge proceedings did not actually commence until May of 1994, after the "Don't Ask, Don't Tell" policy had taken effect.

Acting under the new policy, the Federal Recognition Withdrawal Board found that Lieutenant Holmes' statement concerning his homosexual orientation created a rebuttable presumption that he had engaged in, or was likely to engage in, homosexual conduct. Lieutenant Holmes did not attempt to rebut the presumption, perhaps because, as he would later argue, there seems to be no way of rebutting the presumption short of recanting the statement. ${ }^{171}$ In the end, Lieutenant Holmes' federal recognition was withdrawn. California Adjutant General Tandy $\mathrm{K}$. Bozeman, under the authority of Governor Pete Wilson, then discharged him from the CARNG.

Lieutenant Holmes commenced an action to challenge his discharge from both the CARNG and the ARNGUS in February of 1995. He named as defendants Secretary of Defense William J. Perry, the ARNGUS, and the United States (the "Federal defendants"), as well as Adjutant General Bozeman, Governor Wilson, and the CARNG (the "California defendants"). Chief among Lieutenant Holmes' thirteen claims were alleged violations of his First Amendment (free speech) and Fifth Amendment (equal protection) rights under the United States Constitution, and alleged violations by the California defendants of his free speech, equal protection, and privacy rights under the California Constitution.

169. The following facts, which were not in dispute, are culled from the district court's order.

170. Holmes v. California Army Nat'1 Guard, 920 F. Supp. 1510, 1517 (N.D. Cal. 1996).

171. See id. at 1528. 
The Federal defendants filed a motion to dismiss, and Lieutenant Holmes answered with a cross-motion for summary judgment. The district court dismissed most of Lieutenant Holmes' claims. ${ }^{172}$ However, the court granted summary judgment in his favor on the free speech and equal protection claims. ${ }^{173}$ The court ordered the Federal defendants to restore Lieutenant Holmes to his previous position in the ARNGUS.

The California defendants also filed a motion to dismiss, attacking Lieutenant Holmes' claims against them on three different levels. First, they contended that they could not be held liable for their part in discharging Lieutenant Holmes, because federal law required their actions. Second, they argued that Lieutenant Holmes could not bring his state law claims in federal court. Finally, they attacked the merits of those claims.

The district court rejected the California defendants' first defense, holding that federal law did not preempt the California defendants' authority over Lieutenant Holmes' employment in the CARNG. ${ }^{174}$ Consequently, the court held the California defendants jointly liable for the federal constitutional violations and ordered them to reinstate Lieutenant Holmes in the CARNG. However, the court agreed with the California defendants that it did not have jurisdiction to consider Lieutenant Holmes' state law claims. Accordingly, the court dismissed those claims without prejudice, leaving them untested. Lieutenant Holmes' attorney has expressed an intent to pursue the claims in state court. ${ }^{175}$ Meanwhile, the entire case has been appealed to the Ninth Circuit.

\section{III}

\section{The Federal recognition ARgument}

Holmes posits that the increasing "federalization" of the National Guard since 1903 has not deprived the states of a meaningful role in the administration of their militias. The court strongly rejected the California defendants' claim that Lieutenant Holmes' discharge was mandated by federal policies which the defendants had no power to resist. That claim was supported by two legal theories, which I shall refer to, respectively, as the "federal recognition argument" and the "discipline power argument." In the next two Parts, I analyze the Holmes court's treatment of these issues as framed by the parties. I also

172. See id. at 1536-37.

173. See id. at 1536.

174. See id. at 1522-25.

175. See Reynolds Holding, Judge Rules Against "Don't Ask" Policy, S.F. Chron., Mar. 30, 1996, at A5. As this Comment was going to press, Holmes did indeed file suit in a Califomia Superior Court. 
explore some arguments that the parties did not raise in Holmes but which might be of concern in future cases.

The California defendants first argued that once Lieutenant Holmes' federal recognition was withdrawn, federal law required them to discharge him from the CARNG. This "federal recognition argument" was based on 32 U.S.C. $\S 324(a)$. That section is the present-day statutory incarnation of a provision of the National Defense Act of 1916 that pertains to federal recognition of National Guard officers.

\section{A. The Argument and Its Resolution in Holmes}

The California defendants contended that section 324(a) requires the discharge of a National Guard officer whose federal recognition is withdrawn, leaving state military officials with no choice in the matter. ${ }^{176}$ Lieutenant Holmes countered by arguing that, so construed, the statute would be a violation of the officering power reserved to the states in the Second Militia Clause. Therefore, he suggested, the district court should interpret the statute in a way that would avoid a constitutional dilemma.

The district court adopted the California defendants' reading of the statute, finding no room for the construction advanced by Lieutenant Holmes. ${ }^{177}$ However, the court agreed that a direct federal order to the states requiring the discharge a state military officer solely on the basis of lost "federal recognition" is inconsistent with the Second Militia Clause. ${ }^{178}$ The court was therefore forced to confront the statute's apparent constitutional infirmity.

The court resolved the problem by holding that section 324(a) is coustitutional insofar as it represents a condition attached to federal spending on state Guards. ${ }^{179}$ Consequently, the court concluded that the California defendants were not under the sway of preemptive federal law when they discharged Lieutenant Holmes; they had voluntarily submitted to federal authority in exchange for federal funds. ${ }^{180}$ Instead of asserting the state's right, under the officering power, to choose its National Guard officers, the California defendants discharged Lieutenant Holmes so as not to risk the loss of any funding. The choice was theirs; having voluntarily taken the path that ultimately led them to violate Lieutenant Holmes' constitutional rights, they could not pass the blame on to the Federal defendants. Thus, the "federal recognition argument" failed.

176. See Holmes, 920 F. Supp. at 1522.

177. See id.

178. See id.

179. See id. at 1524.

180. See id. at 1523-24. 


\section{B. Interpreting Section 324(a): Could the Court Have Avoided the Problem?}

Section 324(a) provides that "[a]n officer of the National Guard shall be discharged when ... his Federal recognition is withdrawn."18t Given the dual nature of the National Guard, the statute is ambiguous at first blush. Lieutenant Holmes urged the court to interpret "National Guard" as referring only to the federal Guard. The California defendants maintained that the language referred to the state Guards.

The problem with the California defendants' interpretation is that it raises a difficult constitutional question. ${ }^{182}$ The Second Militia Clause plainly reserves the "appointment of the officers" of the militia, and hence, the National Guard, to the states. However, section 324(a) appears to order the states to discharge those officers if they lose "federal recognition," a concept created by Congress one-hundred and thirty years after the Philadelphia Convention. This forces one to ask, as Frederick Wiener did some time ago, how the federal government can "eo nomine terminate an appointment the making of which is reserved to the States." 183

Lieutenant Holmes suggested that the court could avoid this question by exploiting the ambiguity in the term "National Guard." If "National Guard" were constrned in section 324(a) to mean the federal Guard, then the statute would compel the discharge of a "derecognized" officer only from the federal Guard. Obviously, this interpretation would have benefited Lieutenant Holmes by undermining the California defendant's "federal recognition argument." However, Lieutenant Holmes' constrnction is also objectively attractive, because it disburdens the statute of what seems to be a serious constitutional infirmity.

Nonetheless, the district court properly resisted the temptation to adopt the less-problematic interpretation. The definitions applicable to Title XXXII leave no room for the semantic maneuver proposed by Lieutenant Holmes. Those definitions provide, first, that "National Guard' means the Army National Guard and the Air National Guard."184 Second, "Army National Guard" means the federallyrecognized "part of the organized militia of the several [s]tates ...."185 Third, this "Army National Guard" is distinguished from the "Army National Guard of the United States" (ARNGUS). ${ }^{186}$ There is no reason

\footnotetext{
181. 32 U.S.C. \$ 324(a) (1994).

182. See Wiener, supra note 45 , at 212 n.173.

183. Id.

184. See 32 U.S.C. § 101(3) (1994).

185. Id. § 101 (4) (1994) (emphasis added).

186. Id. \$ 101(5) (1994).
} 
to believe that these definitions, which are generally applicable to all of Title XXXII, do not apply to section 324(a). Thus, one is forced to conclude that "National Guard," as employed in section 324(a), refers to the militias "of the several [s]tates" 187 and not the federal Guard.

Indeed, the statute would make little sense if interpreted otherwise. Section 324(a) comes into play only when a National Guard Officer has lost federal recognition. The act of withdrawing federal recognition itself fundamentally alters the Guardsman's status in the federal military. In short, he loses his place in the federal Guard. Discharge from the federal Guard would at this point be superfluous. Therefore, section 324(a) has nothing to add to the process-it would be a pointless statute-unless it effects the additional step of removing the officer from the state Guard.

\section{Federal Recognition and the Second Militia Clause: Is There Really a Conflict?}

The apparent conflict between section 324(a) and the Second Militia Clause cannot be avoided by exploiting any perceived ambiguity in the statute. Thus, ironically, the California defendants, by winning the debate over what section 324(a) means, exposed the statute, and themselves, to a constitutional challenge. Apparently confident that the interpretation question was dispositive, and failing to appreciate the deeper problem, the California defendants neglected to brief the court on the constitutional issue. ${ }^{188}$ Therefore, it is not surprising that the district court rejected the "federal recognition argument."

Nonetheless, we might inquire whether the inconsistency that appears at first glance between section 324(a) and the Second Militia Clause really exists. In this section, I attempt to define more clearly the intent of the Framers and the nature of the federal recognition system. In section D, I shall examine what little guidance exists in the case law and commentary. Finally, in section E, I shall review what the Holmes court found to be section 324(a)'s constitutional basis: conditional spending.

The significance of the reservation of the officering power to the states must not be underestimated. As one commentator has observed, " $t]$ his last power was considered critical. Many framers feared that a federally-controlled militia would be used against individual states. If militia officers were appointed by their friends at the state level,

187. Id. \$ 101(4) (1994).

188. In fact, the California defendants' briefs, authored by Andrew Loomis of the California Attomey General's Office, caused a bit of a scandal, as they were Iong on anti-homosexual invective and short on legal analysis. See Holmes v. California Army Nat'l Guard, 920 F. Supp. 1510, 1519 n.8 (N.D. Cal. 1996). 
however, their ultimate loyalty would be to the state, and this would safeguard against federal oppression." 189 Alexander Hamilton pressed this point during the ratification debates. Hamilton, whose proposal for federal control over militia officer appointments ${ }^{(91)}$ the Philadelphia Convention rejected, had become aware enough of the importance of the officering power to ask the citizens of New York:

What reasonable cause of apprehension can be inferred from a power in the Union to prescribe regulations for the militia, and to command its services when necessary, while the particular states are to have the sole and exclusive appointment of the officers? If it were possible seriously to indulge a jealousy of the militia upon any conceivable establishment under the federal government, the circumstance of the officers being in the appointment of the States ought at once to extinguish it. There can be no doubt that this circumstance will always secure to them a preponderating influence over the militia. ${ }^{191}$

It must be recognized, then, that the officering power was considered by those who wrote and ratified the Constitution to be an indispensable aspect of state sovereignty.

Nonetheless, one might argue that the federal recognition system is not necessarily inconsistent with the officering power. After all, the federal government does not attempt to "appoint" any particular individuals. ${ }^{192}$ It merely establishes a set of minimum qualifications, which narrow the available pool of candidates from which the states may select its officers. Indeed, supporters of the National Defense Act of 1916 compared the federal recognition system to the provisions of the Constitution setting forth minimum qualifications for election to Congress: "The provision for federal control of the appointment of officers, through the recognition procedure, was defended by analogy to the election of Senators and Representatives; such persons were federal officers though, assuredly, they were selected by the people of the States."193

This analogy, however, does not withstand scrutiny. First, the Constitution specifically contemplates that certain minimum qualifications for membership in Congress would be established at the national

189. Hirsch, supra note 38 , at 925 .

190. See FARRAND, supra note 39, at 293.

191. The Federalist No. 29, at 172 (Alexander Hamilton) (Henry Cabot Lodge ed., 1888) (emphasis in original).

192. See Committee on Civilian Components, Reserve Forces for National Security (1948), quoted in RIKER, supra note 24, at $98-99$ ("If an officer is unsatisfactory, [the Army or Air Force] can withhold or withdraw his federal recognition, but cannot exercise initiative to supply a satisfactory one.").

193. Wiener, supra note 45 , at 202. 
level. ${ }^{194}$ There is no corresponding provision in the Constitution explicitly setting forth minimum qualifications for commissions in the militia, nor even a hint that the federal government would have the power to set those standards in the future. If we take Hamilton at his word-and he of all people should know ${ }^{195}$ - the officering power reserved to the states is "sole and exclusive." 196

Second, comparison with Senators and Representatives is unwarranted, because those officials do not have the dual status that National Guard officers have. Congress is a national institution composed of federal officials. The militia, however, is a state institution, despite the adoption of the term "National Guards." It is only since 1933-well after the drafting of the Constitution-that the militia has acquired a separate, parallel legal existence as a component of the national military reserve forces. Congress' decision to "federally recognize" state Guard units and officers cannot deprive the militia of its constitutional status as a state entity any more than a decision by a state legislature to "recognize" a President would turn that President into a state official, subject to state control.

Other attempts to disprove an inconsistency between the officering power and the federal recognition system are similarly doomed to failure. One could try to analogize the appointment of militia officers to the appointment of federal executive officials, over whom the Senate enjoys a veto power. ${ }^{197}$ However, the analogy plainly fails because the "Advice and Consent Clause"198 explicitly grants such a power, whereas the Second Militia Clause does not. Therefore, it does not appear possible to deny the basic tension between the Second Militia Clause and the federal recognition system, particularly section 324(a).

\section{The Courts, the Commentators, and California}

Mahon, reviewing the drafting of the Militia Clauses, determined that "[o]nly case-by-case interpretation could make it clear what exactly was meant by the power to appoint the officers and to train the militias." 1999 Although considerable attention has been devoted to the

194. See U.S. ConST. art. I, $\S 2$, cl. 2 (requiring that Representatives be twenty-five years of age, citizens for seven years, and inhabitants of their respective states when elected); see id. $\$ 3$, cl. 3 (mandating that senators be thirty years of age, citizens for nine years, and inhabitants of their respective states when elected); see also id. art. 11, $\S 1, \mathrm{cl} .5$ (establishing minimum qualifications for the presidency).

195. After all, it was he who had unsuccessfully tried to establish federal influence over militia officers. See supra note 190 and accompanying text.

196. See supra note $19 \mathrm{I}$ and accompanying text.

197. See U.S. ConsT. art. II, § 2, cI. 2.

198. Jd.

199. MahoN, supra note 15, at 49. 
training power, ${ }^{200}$ substantial "case-by-case interpretation" of the officering power has failed to materialize. Indeed, such case law is extremely sparse.

In United States ex rel. Gillett v. Dern, ${ }^{201}$ one of a series of cases that followed the enactment of the Selective Service Act of 1933 and the adoption of the dual enlistment system, a Court of Appeals remarked that "[t]he United States has not appointed, and constitutionally cannot appoint or remove (except after being called into federal service), officers of the National Guard."2012 The court also indicated that the federal government may not vacate a commission granted by a state governor. ${ }^{203}$ The court's pronouncements, however, arguably have the force only of dicta; the real issue in the case was whether the federal government could condition the receipt of federal pay on the surrender of a government pension. Apparently, only one other federal court had weighed in on the officering issue before the Holmes case. ${ }^{214}$

Commentators, meanwhile, have long viewed the constitutionality of the federal recognition system with suspicion. Wiener, we have seen, early identified the problem of the "apparent conflict between the statutory requirements for federal recognition of officers and the constitutional reservation of their appointment to the States." ${ }^{205}$ However, aside from noting that the system "sharply curtailed"206 the officering power-raising a "very difficult constitutional question"2017-Wiener ultimately reached no conclusion about the issue. Mullins, however, unequivocally finds that the officering power "has been completely vitiated by the 'federal recognition' system," which "effectively wrest[s] from the states control over officer-appointment standards." ${ }^{208}$

The Dern case, Wiener, and Mullins all support the Holmes court's decision to reject the California defendants' "federal recognition argument." Indeed, it is evident that those authorities influenced the court to some degree. ${ }^{209}$ However, perhaps nothing was more influential on the

200. See, e.g., Mullins, supra note 45. The leading case on this subject, as well as the First Militia Clause, is Perpich v. Dep't of Defense, 496 U.S. 334 (1990).

201. 74 F.2d 485 (D.C. Cir. 1934).

202. Id. at 487 (emphasis added).

203. See id. at 488.

204. See MacFarlane v. Grasso, 696 F.2d 217, 226 n.4 (2d. Cir. 1982) ("[S]election and appointment of Army National Guard officers is solely a state responsibility."). The California defendants in Holmes may have been the first litigants to assert that section 324(a) is a direct order to the states, adherence to which is compelled by the Supremacy Clause. This possibly explains the dearth of case law on point.

205. Wiener, supra note 45 , at 211 .

206. Id. at 201 .

207. Id. at 212 n.173.

208. Mullins, supra note 45 , at 343,335 .

209. See Holmes v. California Army Nat'l Guard, 920 F. Supp. 1510, 1521-24 (N.D. Cal. 1996). 
court than the past conduct of California officials, conduct which directly contradicted the position of the California defendants.

As early as 1948, an official California Attorney General opinion remarked that withdrawal of federal recognition does not deprive a National Guard officer of his state commission. ${ }^{210}$ Indeed, the California legislature has authorized the commissioning of some individuals with prior military experience even if they "are no longer eligible for federal recognition."211 In contrast, no California statute expressly requires the discharge of an officer who loses federal recognition.

A recent Ninth Circuit case, ${ }^{212}$ which apparently had a devastating effect on the California defendants' argument, ${ }^{213}$ illustrates that a National Guard officer who loses federal recognition may yet continue to serve in his state capacity. Archer Frey was a colonel in the California National Guard. In 1985, Frey's federal recognition was withdrawn because he had attained thirty years of commissioned service, the maximum allowable term for his rank under federal law. At that point, the court noted, "he ceased to be a member of the [ARNGUS]."214 Despite his loss of federal recognition, however, Frey continued to serve as a military officer in the California National Guard until 1991. ${ }^{215}$ In a footnote quoted by the Holmes court, the Ninth Circuit explained that "[a]s in Frey's case, one may be a member of the State National Guard, but not a member of the army or Air National Guard of the United States."216 In a subsequent footnote-also quoted by the Holmes court - the Ninth Circuit enumerated the consequences of losing federal recognition: "The loss of federal recognition means that the officer no longer participates in federally-paid duty status, which includes activities such as drills, annual training, or service schools at any cost to the federal government, nor may he be called into active federal service."217 The Holmes court remarked, "Significantly absent from this list of consequences is 'automatic discharge.' Such a consequence would in fact render the enumerated consequences irrelevant."218 The Holmes court might also well have noted the Ninth Circuit's detailed effort to make it clear that even after losing federal recognition, Colonel Frey's status and responsibilities in the California National Guard were essentially the same. $^{219}$

210. See 11 Op. Att'y Gen. 253, 261 (1948).

211. CAL. MiL. \& Vet. Code $\$ 222$ (West 1988).

212. Frey v. California, 982 F.2d 399 (9th Cir. 1993).

213. See Holmes, 920 F. Supp. at 1524.

214. Frey, 982 F.2d at 400 .

215. See id.

216. Id. at $400 \mathrm{n} .2$.

217. Id. at $400 \mathrm{n} .3$.

218. Holmes, 920 F. Supp. at 1524.

219. See Frey, 982 F.2d at 400-01, 403-04. 
Frey did not directly address the federal government's authority to remove a National Guard officer from state service. Rather, it was the state-California-that was trying to discharge Colonel Frey, due to his having reached a state-imposed mandatory retirement age. ${ }^{220}$ Nonetheless, Colonel Frey's six years of "post-recognition" service in the California National Guard presented a problem for the California defendants' assertion that they never have any choice but to apply section 324(a) - a fact that was not lost on the Holmes court. Moreover, the Ninth Circuit's discussion of the impact of loss of federal recognition on state Guard membership seems to presuppose an understanding that continued state service is not inevitably precluded by section 324(a).

\section{E. Conditional Spending and Section 324(a)}

The federal recognition system-particularly section 324(a)-must ultimately look for its constitutional basis in the federal government's spending power, not its war powers. Indeed, Mullins suggests that it is because of its conditional spending nature that the system had never directly been challenged on constitutional grounds, ${ }^{221}$ at least until Holmes.

Riker never approaches the constitutional question per se, but he does explain that "national authority [over officer appointments] is ... mostly negative in the sense that the army and air force can merely urge the states to meet standards of federal recognition."222 Their "one means" of enforcing those standards, Riker states, is to withdraw recognition, ${ }^{223}$ an observation which seems to assume that the federal military cannot directly determine who shall be commissioned or discharged from state service. That assumption is supported in a 1948 governmental report that was critical of the attempt to integrate the National Guard into the armed forces: "Of more damaging effect is the tendency of some states...t to impose incompetent officers upon the organization .... [T] [he only means available to the Federal Government to correct unsatisfactory conditions is to deprive the unit or individual of federal support . ..."224

220. See id. at 399-400. Frey was before the court to challenge his discharge under federal age discrimination laws. The Ninth Circuit determined that the Age Discrimination in Employment Act, 29 U.S.C. $\$ \S 621-34$, which does not apply to the federal military, also does not apply to state militias. See id. at 404 . Therefore, California's mandatory retirement age for military officers was valid.

221. See Mullins, supra note 45 , at 335 .

222. Riker, supra note 24 , at 102 .

223. See id. at 115. Riker comments that this remedy is "far too severe for everyday use," because it results in the loss of reserve units and invites "political recrimination from Congressmen." Id.

224. Id. at 99 (quoting Committee on Civilian Components, Reserve Forces for National Security, 2-14 (1948)). 
The historical studies by Riker, Mahon, and Derthick illustrate that the states voluntarily submitted themselves to increasing federal control over the militia in exchange for increasing levels of federal support and recognition. ${ }^{225}$ The prime example of this trade-off is the federal recognition system. States retain their authority under the Second Militia Clause to select the particular individuals who will receive commissions in the National Guard. If those individuals do not qualify for federal recognition, however, the federal government will not pay for their activities.

Moreover, "no unit receiving federal funds or support may place an officer in its table of organization unless that officer has been federally recognized."226 Consequently, the presence of an "unrecognized" officer can compromise the federal recognition of an entire unit, leading to an even greater loss of funds. Therefore, most, if not all, states primarily commission those individuals who meet federal qualifications. ${ }^{227}$

"Nonetheless," the Holmes court concluded, "at least with respect to personnel decisions, states ultimately choose to comply with federal National Guard policies. At the risk of losing funding, states are free to break from $\S 324$ (a) and to retain in state service officers who lose their federal recognition." ${ }^{228}$ History, commentary, and what little case law there is support that conclusion. The California defendants might have elected to stand up for Lieutenant Holmes-by all accounts an outstanding officer-but they did not. The Holmes court correctly decided that they could not escape liability by deflecting the blame onto the federal recognition system. ${ }^{229}$

\section{IV}

\section{The Discipline Power Argument}

The second theory supporting the California defendants' defense invoked the "Don't Ask, Don't Tell" policy itself. The California

225. See supra Part I.E.

226. Mullins, supra note 45 , at 343.

227. See MacFarlane v. Grasso, 696 F.2d 217, 226 n.4 (2d Cir. 1982); see also CaL. MiL. \& VET. CODE $\$ 222$ (West 1988) ("Persons to be commissioned in the National Guard shall be selected from those eligible for federal recognition....").

228. Holmes v. California Army Nat'l Guard, 920 F. Supp. 1510, 1523-24 (N.D. Cal. 1996) (footnote omitted).

229. The Holmes case leaves open the interesting question of whether the financial pressure exerted on the states to adhere to the federal recognition system has risen to the level of a coercive, unconstitutional condition. Mullins suggests as much. "This scheme supplants the state's role in choosing and installing state officers, for no state's Guard can accomplish federally mandated missions without making use of federal funding and support." Mullins, supra note 45, at 343. However, he notes that the "difficulties in striking down a provision like... the federal recognition system for officers are many," $i d$. at 357 , and finds a full treatment of the issue beyond the scope of his discussion. See id. at 357 n. 218. 
defendants argued that "Don't Ask, Don't Tell" applies directly to state military personnel by virtue of Congress' power to "discipline" the militia. In this Part, I analyze the court's treatment of this argument and conclude that it was correct. It is possible, I shall suggest, that a more rigorous argument from the 'discipline' power than the one presented by the California defendants could be advanced. Though the ultimate merit of the stronger argument is unclear, I shall contend that in any event, the discipline power is not broad enough to support "Don' $t$ Ask, Don't Tell."

\section{A. The California Defendants' Argument: Confusion in the Ninth Circuit}

The jurisprudence touching upon the discipline power is no more developed than the case law pertaining to the officering power. The Ninth Circuit has visited the issue twice, with conflicting results.

First, in Johnson v. Orr, ${ }^{230}$ a lesbian member of the California National Guard brought a federal suit in California to challenge her discharge, which resulted from revealing her sexual orientation. ${ }^{231}$ One of her arguments-apparently not a major one-was that federal regulations regarding homosexuality could not be enforced against her while she was on state duty. Citing only the bare text of the Second Militia Clause, the court explained that Congress has the power to "discipline" the militia and rejected the plaintiff's claim. ${ }^{232}$ The Ninth Circuit, in an unpublished decision, summarily affirmed.

Six years later, the Ninth Circuit would unsuspectingly contradict itself in Gilliam v. Miller. ${ }^{233}$ There, two former members of the Oregon Army National Guard brought suit to challenge their discharges, which resulted from their failure to comply with federal military weight control regulations. Those regulations had been incorporated into Oregon law by statute; however, the plaintiffs argued that the regulations also had the direct force of federal law. Therefore, they contended, the Oregon Adjutant General was acting as a federal agent in applying the regulations. The former Guardsmen invoked this theory in order to state a claim under the federal Administrative Procedures Act.

The district court, adopting the findings of a magistrate judge, initially sided with the plaintiffs. Shortly thereafter, however, the United States Supreme Court announced its decision in Perpich v. Department of Defense, ${ }^{234}$ a case in which the governor of Minnesota sought to

\footnotetext{
230. 617 F. Supp. 170 (E.D. Cal. 1985), aff'd, 787 F.2d 597 (9th Cir. 1986).

231. The policy in effect at the time was the predecessor to "Don't Ask, Don't Tell."

232. See Johnson, 617 F. Supp. at 177.

233. 973 F.2d 760 (9th Cir. 1992).

234. 496 U.S. 334 (1990).
} 
prevent the federal military from sending units of the Minnesota Army National Guard to Honduras for "training," citing the First Militia Clause's limit on federal use of the militia. The Supreme Court, in a move that should have surprised no one, held that once Guard units are called into active federal duty, they are a part of the army, and the federal government can do anything it wants with them. In reaching that conclusion, however, the Court engaged in an extensive analysis of the National Guard's dual legal existence. Most significantly, the Court commented that under the dual enlistment system, National Guardsmen "now must keep three hats in their closets-a civilian hat, a state militia hat, and an army hat-only one of which is worn at any particular time." ${ }^{235}$ This comment, and others in the opinion, seem to suggest that, when not in active federal service, the National Guard is subject to state law and control.

Indeed, after Perpich was handed down, the Oregon Adjutant General moved for reconsideration of the Gilliam ruling. The district court granted the motion and, employing the language of Perpich, held that the Adjutant General had been wearing his "state militia hat" when he discharged the plaintiffs. The court reversed its earlier finding and dismissed the complaints.

The Ninth Circuit, without any acknowledgment of Johnson v. Orr, affirmed. The court explained that, although the regulations affecting the plaintiffs were originally promulgated by the federal government, their legal effect derived from the act of the Oregon legislature in incorporating federal military regulations into state law. ${ }^{236}$ Thus, when the Adjutant General discharged the plaintiffs from state service, he did so "solely in the capacity of a state actor," "fulfilling his role under state law," and not "under federal control." "237 This conclusion, one immediately recognizes, is inconsistent with Johnson v. Orr, which holds that federal military regulations apply directly to National Guardsmen even while in state service because of the discipline power. The Ninth Circuit, unintentionally or otherwise, failed to mention Johnson, much less distinguish it. ${ }^{238}$ Therefore, the district court in Holmes was forced to deal with an apparent conflict of authority on the issue.

The Holmes court found that Johnson and Gilliam are indeed irreconcilable. The court concluded that Gilliam controlled, finding that it expressed the Ninth Circuit's present view of the issue. Accordingly, the

235. Id. at 348.

236. See Gilliam, 973 F.2d at 761 n.2, 763.

237. Id. at 764.

238. Rather, the Ninth Circuit cited an older Connecticut case which reached a similar conclusion. See Zitser v. Walsh, 352 F. Supp. 438, 440 (D. Conn. 1972) (holding that where Connecticut Army National Guard colonel used a federally-promulgated regulation to determine an applicant's officer qualifications, "state law commanded him to apply that regulation"). 
court rejected the California defendants' argument that "Don't Ask, Don't Tell" necessarily applied to Holmes even while in state service. Having already lost the "federal recognition argument," the California defendants' defense thus collapsed entirely.

The court's disposition of the Johnson/Gilliam conflict is quite defensible. The Gilliam court had the benefit of the Supreme Court's analysis of the National Guard in Perpich, and therefore can be presumed to represent a more considered view of the issue. The Gilliam decision is also attractive because it resolves what would otherwise be an embarrassing pronouncement on state legislatures. The problem is as follows. Assume that, as stated in Johnson, federal military regulations apply automatically, of their own force, to militia personnel in state service. Along comes the Oregon state legislature (or the California legislature, for that matter), which adds to its state militia codes a statute that adopts, into state law, all federal military regulations. In doing so, the state legislature purports to be making law. But this gesture is a shamthe federal regulations are already in effect, whether the state legislature "adopts" them or not.

In Gilliam, the Ninth Circuit emphatically stated that "[t]he adoption of federal training requirements for members of [the Oregon Army National Guard] by the Oregon Legislature was not a sham."239 Thus, Gilliam affords respect to what would otherwise have to be considered empty statutes. It is easy to see, then, why the Holmes court elected to follow Gilliam rather than Johnson.

\section{B. Beyond the Ninth Circuit: What is Discipline, Who Administers It, and When?}

The Holmes court, beholden as it was to Ninth Circuit case law, had no occasion to call into question the Gilliam doctrine. The court's analysis ended when it determined that Gilliam controlled. For our purposes, however, the more interesting question is not whether Gilliam controls, but whether Gilliam was correctly decided.

The Johnson rule, after all, is not patently unreasonable. The Second Militia Clause does indeed grant Congress the power to discipline the militia. The power is unqualified by any explicit limitations. How, then, can one maintain that regulation of the militia is not a federal concern? On the other hand, if Johnson is right, what are we to make of the Supreme Court's comment that a National Guardsmen wears only one "hat" at a time?

Framing the issue this way, I think, misses the mark. There should be little doubt that the discipline power extends to the militia even while

239. Gilliam, 973 F.2d at 763 . 
in state service. When the Second Militia Clause came before the Philadelphia Convention, an amendment was proposed which would have expressly tied the federal government's Second Militia Clause powers to the First Militia Clause. ${ }^{241}$ More specifically, the United States would have the authority to organize, arm, and discipline the militia only when the militia had actually been called out to suppress insurrections or repel invasions. That amendment was rejected, as was another that "would have left all the actual supervision of the militia in state hands." ${ }^{241}$ Finally, the objections registered by anti-federalists during the ratification debates suggest that it was understood all too well that, under the Constitution, the discipline of the militia is a federal prerogative.

That is not to say that the states lack any control over the discipline of their militias. Ample evidence exists to demonstrate that the Framers intended the power to discipline to be concurrent. ${ }^{242}$ However, the Second Militia Clause puts federal authority ahead of state authority. A good number of arguments could be made that this arrangement does not adequately safeguard the interests of the states in controlling their militias. Those arguments were made in 1787 and in the years that followed, and they are certainly not without merit. The fact is, however, that they lost. A policy choice was made; the federal government would have, if it cared to exercise them, strong powers over the organization, armament, and discipline of the militia. If the officering power is to be defended against federal encroachment, as I have argued it should be, then the discipline power must be defended against repudiation by the states. One cannot have it both ways. Therefore, while the Holmes court was right to follow Gilliam instead of Johinson as a matter of trying to predict what the Ninth Circuit would require, some of the assumptions about the discipline power in Gilliam are suspect.

\section{Discipline and Homosexuality}

As I suggested earlier, however, Johnson and Gilliam are (or at least should be considered) somewhat beside the point. Framing the issue in terms of who has the exclusive, or superior, authority to discipline the militia while in state service affords an opportunity for historical analysis but not much real debate. The real question to be answered is, what does it mean to "discipline" the militia? Johnson, Gilliam, and indeed Holmes assume that what the federal government was doing to the Guardsmen involved was in fact "discipline." But was it?

\footnotetext{
240. See RIKER, supra note 24, at 16.

241. Id.

242. See id. at 17 .
} 
Some evidence suggests that "discipline" refers merely to methods of training and fighting, and perhaps a unified command structure. John Jay, arguing in support of the Constitution during ratification, pointed to the fact that it brought the militia under "one plan of discipline. ${ }^{243}$ He contrasted this state of affairs with a dire hypothetical in which Great Britain, faced with an invasion, finds to its dismay that the English, Scottish, and Welsh militias will obey only their regional governments, leaving the greater nation unable to mount a unified defense. ${ }^{244}$ These comments suggest a real concern behind the discipline power is that the state militias would be subject to a single authority in times of need. This interpretation is buttressed by the other appearance of the word "discipline" in the Second Militia Clause. Recall that the clause grants to the states the authority to train the militia, "according to the discipline prescribed by Congress." ${ }^{245}$ Thus, the Constitution itself seems to draw a close connection between "discipline" and training. In addition, Wiener notes that, in the early militia acts, "discipline" was synonymous with a "system of drill."246

On the other hand, "discipline" is readily associated with punishment as well. It is in the context of this connotation that much of the anti-federalist opposition to the Militia Clauses becomes intelligible; it was feared that the federal government would impose "severe and ignominious punishments on the militia."247 Reviewing the history of court-martial tribunals and the National Guard, Wiener concludes that "it seems fairly clear that Congress has the power to regulate courtsmartial in the state militia [even] when not in federal service, and that such was the understanding of the Founders."248

The evidence of original intent, however, is fairly mixed. Moreover, considering that the "Founders" were of many minds, not one, it is difficult to say what the disciplining power was meant to encompass. Another problem is that military "discipline" has expanded, like many other things, beyond the contemplation of eighteenth century politicians. Thus, the precise scope of the disciplining power remains unclear, all the more so because cases like Johnson and Gilliam focus on when that power may be exercised and not on how or for what pnrposes. Recall that Johnson, like Holmes, involved the regulation of homosexuality, while Gilliam involved a weight control regulation. Are these the types of "discipline" that are, or should be, of national concern?

\footnotetext{
243. Id. at 13.

244. See id.

245. U.S. CoNST. art. I, \& 8, cl. 16.

246. Wiener, supra note 45 , at 214 .

247. Id. at 214 n.189 (quoting 3 ElLIOT's DeBates 416 (1836)).

248. Id. at 215 .
} 
They may or may not be, but it is an issue that the courts have neglected.

In any event, a strong argument can be made that whatever the discipline power may allow, it does not extend to such a wide-sweeping regulation as "Don't Ask, Don't Tell." Of course, "Don't Ask, Don't Tell" may be described as a disciplinary policy, so that one may then invoke the discipline power and conclude that the policy applies directly to militiamen even while in state service. So long as the policy only affects a few individuals, there might be little objection to this approach, as it would appear to be narrowly tailored to particular cases.

However, in practical effect the policy excludes an entire category of persons from military service. From this perspective, it looks less like a disciplinary policy and more like a disqualification. As the discipline power expands under such a policy, it threatens to consume the officering power. If the federal government can impose, in the name of "discipline" or "fitness," regulations that effectively prohibit states from employing homosexuals, it seems logical that it might also prohibit employment of individuals over a certain weight (Gilliam) or age. Meanwhile, the states, which may yet have great use for individuals who do not fit the federal ideal, find that, officering clause notwithstanding, their hands are tied.

The challenge for the courts, then, is to explore the intersection of the discipline and officering powers and balance the interests of the federal and state governments with respect to the militia. If California, or any other state, determines that it benefits from the service of homosexuals, or any other class of persons, indeed any individual, does the disciplining power trump the state's discretion under the officering power? All the time? Only in certain cases? Is Holmes one of them? Or does the officering power prevail?

So far, the courts have provided no answers. For what it is worth, I might suggest that because the Constitution guarantees the states a continuing role in the administration of the militia, federal policies that constrain the states' control over who will serve in their militias should be subjected to greater scrutiny than any mere "rational basis" test-the more constraining, the higher the scrutiny. Whatever justification the federal government has for excluding homosexuals from federal military service, that justification must be more than minimal if the policy is to be imposed on the states as well.

\section{CONCLUSION}

The "federal recognition argument," however one might attempt to bolster it, lacks merit and was properly rejected by the Holmes court. The "discipline power argument," on the other hand, might be pressed 
more rigorously than it was in Holmes and with a greater chance of success. I have argued, nonetheless, that at a minimum, imposition of "Don't Ask, Don't Tell" upon state militias requires greater justification than the "rational basis" that is offered when the policy itself is challenged. Another defensible position is that the officering clause must prevail. In this legal no-man's-land, however, it is difficult to make the case for that position-or, indeed, its opposite-authoritatively.

This Comment leaves unexplored the state law issues raised in Holmes v. California Army National Guard. Those issues, however, should not be forgotten, or else one may underestimate the consequences of how one answers the federalism questions. In this discussion, I have focused on a distinction between federal control and state choice. It is not necessarily the case, I should point out, that any particular state would have a choice between adhering to or rejecting "Don't Ask, Don't Tell" even if freed from federal control.

It is possible that some states would actually be required, under their own laws, to break with "Don't Ask, Don't Tell." The Supreme Court of Kentucky, for example, has held that anti-sodomy laws violate privacy rights implicit in the state's constitution. ${ }^{24 y}$ California's Constitution contains an explicit guarantee of privacy, ${ }^{250}$ raising the possibility of a similar judgment at some point. Moreover, the California Supreme Court has squarely held that California's equal protection guarantee applies to homosexuals. ${ }^{251}$ Thus, it is not unlikely that courts in some jurisdictions would strike down "Don't Ask, Don't Tell," a discriminatory policy based on sexual orientation. For homosexual Guardsmen who hope to be able to serve their states, challenging "Don't Ask, Don't Tell" under the Militia Clauses may be the first step on the road to a greater victory.

249. See Commonwealth v. Wasson, 842 S.W.2d 487, 491 (Ky. 1992).

250. CAL. Const. art. I, $\$ 1$ (West 1996).

25I. See Gay Law Students Ass'n v. Pacific Tel. \& Tel. Co., 595 P.2d 592, 597 (1979). 